This Supplemental Material accompanies Gooley, J.T., Grove, M., and Graham, S.A., 2021, Tectonic evolution of the central California margin as reflected by detrital zircon composition in the Mount Diablo region, in Sullivan, R., Sloan, D., Unruh, J.R., and Schwartz, D.P., eds., Regional Geology of Mount Diablo, California: Its Tectonic Evolution on the North America Plate Boundary: Geological Society of America Memoir 217, https://doi.org/10.1130/2021.1217(14).

\title{
TECTONIC EVOLUTION OF THE CENTRAL CALIFORNIA MARGIN AS REFLECTED BY DETRITAL ZIRCON COMPOSITION IN THE MOUNT DIABLO REGION
}

\author{
Jared T. Gooley, Marty Grove, and Stephan A. Graham
}

\section{Supplementary Materials}

\section{Summary of Contents}

Appendix S1: Geologic Map Data Sources

Appendix S2: Sample Preparation and Analytical Methods

Table S1: U-Th-Pb Isotopic Composition of Detrital Zircon Analyzed at the University of

\author{
Arizona LaserChron Center
}

Table S2: Relative Abundance of Dominant U-Pb Age Components 


\section{Appendix S1: Geologic Map Data Sources}

The geologic map of the Mount Diablo region in Figure 1B was assembled by stitching and digitizing 23 maps at 1:24,000 scale (Dibblee and Minch; 2005a-m, 2006a-i). Additionally, the 1:75,000 scale map of Graymer et al. (1994) was used to crosscheck map units and complete missing areas. References are found below.

\section{REFERENCES}

Dibblee, T.W., and Minch, J.A., 2005a, Geologic map of the Benicia quadrangle, Contra Costa \& Solano Counties, California: Dibblee Geological Foundation, Dibblee Foundation Map DF-146, scale 1:24,000.

Dibblee, T.W., and Minch, J.A., 2005b, Geologic map of the Briones Valley quadrangle, Contra Costa \& Alameda Counties, California: Dibblee Geological Foundation, Dibblee Foundation Map DF-148, scale 1:24,000.

Dibblee, T.W., and Minch, J.A., 2005c, Geologic map of the Diablo quadrangle, Contra Costa and Alameda Counties, California: Dibblee Geological Foundation, Dibblee Foundation Map DF-162, scale 1:24,000.

Dibblee, T.W., and Minch, J.A., 2005d, Geologic map of the Dublin quadrangle, Contra Costa and Alameda Counties, California: Dibblee Geological Foundation, Dibblee Foundation Map DF-164, scale 1:24,000.

Dibblee, T.W., and Minch, J.A., 2005e, Geologic map of the Hayward quadrangle, Contra Costa and Alameda Counties, California: Dibblee Geological Foundation, Dibblee Foundation Map DF-163, scale 1:24,000.

Dibblee, T.W., and Minch, J.A., 2005f, Geologic map of the La Costa Valley quadrangle, Alameda County, California: Dibblee Geological Foundation, Dibblee Foundation Map DF-152, scale 1:24,000.

Dibblee, T.W., and Minch, J.A., 2005g, Geologic map of the Las Trampas Ridge quadrangle, Contra Costa and Alameda Counties, California: Dibblee Geological Foundation, Dibblee Foundation Map DF-161, scale 1:24,000.

Dibblee, T.W., and Minch, J.A., 2005h, Geologic map of the Mare Island quadrangle, Contra Costa, Solano, Marin, \& Sonoma Counties, California: Dibblee Geological Foundation, Dibblee Foundation Map DF-145, scale 1:24,000.

Dibblee, T.W., and Minch, J.A., 2005i, Geologic map of the Newark quadrangle, Alameda County, California: Dibblee Geological Foundation, Dibblee Foundation Map DF-150, scale $1: 24,000$.

Dibblee, T.W., and Minch, J.A., 2005j, Geologic map of the Niles quadrangle, Alameda County, California: Dibblee Geological Foundation, Dibblee Foundation Map DF-151, scale $1: 24,000$. 
Dibblee, T.W., and Minch, J.A., 2005k, Geologic map of the Oakland East quadrangle, Contra Costa and Alameda Counties, California: Dibblee Geological Foundation, Dibblee Foundation Map DF-160, scale 1:24,000.

Dibblee, T.W., and Minch, J.A., 20051, Geologic map of the Richmond quadrangle, Contra Costa \& Alameda Counties, California: Dibblee Geological Foundation, Dibblee Foundation Map DF-147, scale 1:24,000.

Dibblee, T.W., and Minch, J.A., 2005m, Geologic map of the Walnut Creek quadrangle, Contra Costa County, California: Dibblee Geological Foundation, Dibblee Foundation Map DF149 , scale $1: 24,000$.

Dibblee, T.W., and Minch, J.A., 2006a, Geologic map of the Altamont quadrangle, Alameda County, California: Dibblee Geological Foundation, Dibblee Foundation Map DF-197, scale 1:24,000.

Dibblee, T.W., and Minch, J.A., 2006b, Geologic map of the Antioch South \& Brentwood quadrangles, Contra Costa County, California: Dibblee Geological Foundation, Dibblee Foundation Map DF-193, scale 1:24,000.

Dibblee, T.W., and Minch, J.A., 2006c, Geologic map of the Byron Hot Springs \& Clifton Court Forebay quadrangles, Contra Costa, Alameda, \& San Joaquin Counties, California: Dibblee Geological Foundation, Dibblee Foundation Map DF-195, scale 1:24,000.

Dibblee, T.W., and Minch, J.A., 2006d, Geologic map of the Cedar Mountain quadrangle, Alameda \& San Joaquin Counties, California: Dibblee Geological Foundation, Dibblee Foundation Map DF-241, scale 1:24,000.

Dibblee, T.W., and Minch, J.A., 2006e, Geologic map of the Livermore quadrangle, Contra Costa \& Alameda Counties, California: Dibblee Geological Foundation, Dibblee Foundation Map DF-196, scale 1:24,000.

Dibblee, T.W., and Minch, J.A., 2006e, Geologic map of the Lone Tree Creek quadrangle, Alameda, San Joaquin, and Stanislaus Counties, California: Dibblee Geological Foundation, Dibblee Foundation Map DF-242, scale 1:24,000.

Dibblee, T.W., and Minch, J.A., 2006f, Geologic map of the Mendenhall Springs quadrangle, Alameda County, California: Dibblee Geological Foundation, Dibblee Foundation Map DF-235, scale 1:24,000.

Dibblee, T.W., and Minch, J.A., 2006g, Geologic map of the Midway \& Tracy quadrangles, Alameda \& San Joaquin Counties, California: Dibblee Geological Foundation, Dibblee Foundation Map DF-243, scale 1:24,000.

Dibblee, T.W., and Minch, J.A., 2006h, Geologic map of the Tassajara quadrangle, Contra Costa \& Alameda Counties, California: Dibblee Geological Foundation, Dibblee Foundation Map DF-194, scale 1:24,000.

Dibblee, T.W., and Minch, J.A., 2006i, Geologic map of the Vine Hill \& Honker Bay quadrangles, Contra Costa \& Solano Counties, California: Dibblee Geological Foundation, Dibblee Foundation Map DF-191, scale 1:24,000. 
Graymer, R.W., Jones, D.L., and Brabb, E.E., 1994, Preliminary geologic map emphasizing bedrock formations in Alameda County, California: a digital database: U.S. Geological Survey Open-file Report OF-96-252 


\section{Appendix S2: Sample Preparation and Analytical Methods}

\section{Mineral Separation for Detrital Zircon Analysis (Stanford University Earth Materials Lab)}

Rock samples were crushed and disaggregated using a Bico-Braun chipmunk jaw crusher and Bico-Braun disk grinder. Disaggregated samples were individually hydrodynamically processed on a Gemini table to concentrate heavy sand fractions. Heavy sand fractions were rinsed in acetone to prevent grains from rusting and then were oven-dried. Less magnetic minerals were concentrated using a sloped Frantz magnetic separator set at a $10^{\circ}$ incline and 100 volts at 0.4 angstroms $(\AA), 0.8 \AA$, and $1.2 \AA$. Separates were then run through methylene iodide (MEI) heavy liquid $\left(\rho=3.32 \mathrm{~g} / \mathrm{cm}^{3}\right.$ ) to collect the final nonmagnetic heavy fraction. Sample separates were sent to the University of Arizona LaserChron center to be mounted individually in a $2.54 \mathrm{~cm}$ (1 inch) epoxy mount with fragments of primary (FC-Z5, 1099 Ma; Paces and Miller, 1993), Sri Lanka (SL-Mix and SL-F; 563.5 Ma; Gehrels et al., 2008) and secondary (R33, 419 Ma; Black et al., 2004) standard zircons. Mounts were polished to half of mean grain thickness $(\sim 20 \mu \mathrm{m})$ for imaging with a back-scattered electron (BSE) detector, using a Hitachi 3400N scanning electron microscope (SEM). The mounts were then polished to expose the zircon grain cores (1500 grit wet/dry sandpaper, followed by $6 \mu \mathrm{m}$, then $1 \mu \mathrm{m}$ diamond powder slurries) on a Struers LabPol5 rotary polisher, and coated with roughly $10 \mathrm{~nm}$ high-purity gold in a Denton sputter coater before analysis.

\section{U-Pb Geochronology Analysis by LA-ICP-MS (University of Arizona LaserChron Center)}

$\mathrm{U}-\mathrm{Pb}$ geochronology of zircons was conducted by laser ablation multicollector inductively coupled plasma mass spectrometry (LA-MC-ICPMS) at the Arizona LaserChron Center (Gehrels et al., 2006, 2008). The analyses involve ablation of zircon with a Photon Machines Analyte G2 excimer laser using a spot diameter of 30 microns. The ablated material is carried in helium into the plasma source of a $\mathrm{Nu}$ HR ICPMS, which is equipped with a flight tube of sufficient width that $\mathrm{U}, \mathrm{Th}$, and $\mathrm{Pb}$ isotopes are measured simultaneously. All measurements are made in static mode, using Faraday detectors with $3 \times 1011 \mathrm{ohm}$ resistors for ${ }^{238} \mathrm{U},{ }^{232} \mathrm{Th},{ }^{208} \mathrm{~Pb}-{ }^{206} \mathrm{~Pb}$, and discrete dynode ion counters for $204 \mathrm{~Pb}$ and $202 \mathrm{Hg}$. Ion yields are $\sim 0.8 \mathrm{mv}$ per ppm. Each analysis consists of one 15-second integration on peaks with the laser off (for backgrounds), 15 one-second 
integrations with the laser firing, and a 30 second delay to purge the previous sample and prepare for the next analysis. The ablation pit is $\sim 15$ microns in depth.

For each analysis, the errors in determining ${ }^{206} \mathrm{~Pb} /{ }^{238} \mathrm{U}$ and ${ }^{206} \mathrm{~Pb} /{ }^{204} \mathrm{~Pb}$ result in a measurement error of $\sim 1-2 \%$ (at 2-sigma level) in the ${ }^{206} \mathrm{~Pb} /{ }^{238} \mathrm{U}$ age. The errors in measurement of ${ }^{206} \mathrm{~Pb} /{ }^{207} \mathrm{~Pb}$ and ${ }^{206} \mathrm{~Pb} /{ }^{204} \mathrm{~Pb}$ also result in $\sim 1-2 \%$ (at 2-sigma level) uncertainty in age for grains that are $>1.0 \mathrm{Ga}$, but are substantially larger for younger grains due to low intensity of the ${ }^{207} \mathrm{~Pb}$ signal. For most analyses, the cross-over in precision of ${ }^{206} \mathrm{~Pb} /{ }^{238} \mathrm{U}$ and ${ }^{206} \mathrm{~Pb} /{ }^{207} \mathrm{~Pb}$ ages occurs at $\sim 1.0 \mathrm{Ga}$. Instrument setup, tuning, run parameters, standard-unknown bracketing, and data reduction followed that of Gehrels and Pecha (2014).

Common $\mathrm{Pb}$ correction is accomplished by using the $\mathrm{Hg}$-corrected $204 \mathrm{~Pb}$ and assuming an initial $\mathrm{Pb}$ composition from Stacey and Kramers (1975). Uncertainties of 1.5 for ${ }^{206} \mathrm{~Pb} /{ }^{204} \mathrm{~Pb}$ and 0.3 for ${ }^{207} \mathrm{~Pb} /{ }^{204} \mathrm{~Pb}$ are applied to these compositional values based on the variation in $\mathrm{Pb}$ isotopic composition in modern crystal rocks. For each sample, the uncertainty in determining ${ }^{206} \mathrm{~Pb} /{ }^{207} \mathrm{~Pb}$ and ${ }^{206} \mathrm{~Pb} /{ }^{238} \mathrm{U}$ ages result in generally $1-2 \%$ (2-sigma) for both. Concentrations of $U$ and Th are calibrated relative to our Sri Lanka zircon, which contains $\sim 518 \mathrm{ppm}$ of U and $68 \mathrm{ppm}$ Th.

\section{U-Pb Geochronology Data Reduction (University of Arizona LaserChron Center)}

$\mathrm{U}-\mathrm{Pb}$ geochronology analyses by LA-ICP-MS were reduced at the University of Arizona LaserChron Center following standard methods (after Gehrels et al., 2006, 2008; https://sites.google.com/a/laserchron.org/laserchron/). Only grains with $<20 \%$ discordance and $<5 \%$ reverse discordance are included in interpretations. Final ages are based on ${ }^{206} \mathrm{~Pb} /{ }^{238} \mathrm{U}$ if younger than $900 \mathrm{Ma}$, and ${ }^{207} \mathrm{~Pb} /{ }^{206} \mathrm{~Pb}$ for ages $>900 \mathrm{Ma}$. Data reduction was performed with an in-house Python decoding routine and a Microsoft Excel spreadsheet (NUagecalc). Analytical data is available in (Table S1).

\section{References}

Black, L. P., Kamo, S. L., Allen, C. M., Davis, D. W., Aleinikoff, J. N., Valley, J. W., and Foudoulis, C., 2004, Improved $206 \mathrm{~Pb} / 238 \mathrm{U}$ microprobe geochronology by the monitoring of a trace-element related matrix effect; SHRIMP, ID-TIMS, ELA-ICP-MS and oxygen isotope documentation for a series of zircon standards: Chemical Geology, v. 205, no. 1, p. $115-140$. 
Gehrels, G.E., Valencia, V., Ruiz, J., 2008, Enhanced precision, accuracy, efficiency, and spatial resolution of $\mathrm{U}-\mathrm{Pb}$ ages by laser ablation-multicollector-inductively coupled plasma-mass spectrometry: Geochemistry, Geophysics, Geosystems, v. 9, Q03017, doi:10.1029/2007GC001805.

Gehrels, G.E., Valencia, V., Pullen, A., 2006, Detrital zircon geochronology by Laser-Ablation Multicollector ICPMS at the Arizona LaserChron Center, in Loszewski, T., and Huff, W., eds., Geochronology: Emerging Opportunities, Paleontology Society Short Course: Paleontology Society Papers, v. 11, 10 p.

Gehrels, G. and Pecha, M., 2014, Detrital zircon U-Pb geochronology and Hf isotope geochemistry of Paleozoic and Triassic passive margin strata of western North America: Geosphere, v. 10, no.1, p. 49-65.

Paces, J.B. and Miller, J.D., 1993, Precise U-Pb ages of Duluth Complex and related mafic intrusions, northeastern Minnesota: Geochronological insights to physical, petrogenetic, paleomagnetic, and tectonomagmatic processes associated with the $1.1 \mathrm{Ga}$ Midcontinent Rift system, Journal of Geophysical Research, v. 98(B8), p. 13997-14013.

Stacey, J.S., and Kramers, J.D., 1975, Approximation of terrestrial lead isotope evolution by a two-stage model: Earth and Planetary Science Letters, v. 26, p. 207-221. 